\title{
Is My Rival's Rival a Friend? Popular Third-Party Perceptions of Territorial Disputes in East Asia
}

\author{
NIV HORESH, HYUN JIN KIM, PETER MAUCH \\ AND JONATHAN SULLIVAN
}

\begin{abstract}
This article examines how China's rise and increasing tensions with Japan are portrayed by South Korean bloggers. The deterioration in relations between China and Japan over the last two years generally projects onto the ways and means by which China's rise is portrayed in South Korea. Since Korea's relations with both its more populous neighbours have been historically fraught, and since it is also implicated in various territorial disputes with both countries, determining Korean sensibilities is an important way of gauging shifts in public opinion across the region. Although the conservative political establishments in both South Korea and Japan might see China as a constant threat, South Korean and Japanese netizens still popularly view each other with suspicion. By contrast, popular perceptions of the China threat in either country can be swayed by escalation of territorial disputes these two US allies still have with one another.
\end{abstract}

Keywords: nationalism, media, Sino-Japanese relations, Sino-Korean relations

\section{Introduction}

China's resurgence on the world stage has clearly manifested itself over the past year in a much bolder stance toward Japan. Partly in response to the Japanese state purchase of the Senkaku/Diaoyutai islets, a boycott of Japanese goods swept across China, seriously affecting bilateral economic relations. Although much attention, for example in the media, throughout this ongoing territorial dispute has been devoted to official positions and interactions, this article instead focuses on the unmediated seam of popular animosity between the two countries as expressed online in blogs. Furthermore, the issue will not be conventionally explored through the prism of Sino-Japanese exchanges, which have already received much attention (Fogel 2010; Lary 2010; Rose 2004; Rozman 2004). 
Rather, we will examine how China's rise and increasing tensions with Japan are portrayed by South Korean bloggers. We do this as part of a broader research agenda that seeks to elucidate third-party popular perceptions of territorial disputes across East Asia. ${ }^{1}$ In other words, we are primarily interested to know how deterioration in relations between China and Japan might project onto the ways and means by which China's rise is portrayed in South Korea. Since Korea's relations with both its more populous neighbours have been historically fraught, and since it is also implicated in various territorial disputes with both countries, determining Korean sensibilities is an important way of gauging shifts in public opinion across the region. How does the flare-up of a regional territorial dispute such as Senkaku/Diaoyu - in which South Korea is not implicated - affect popular South Korean perceptions of China and Japan? Which side is more likely to be seen as a rival, and which side is framed as South Korea's friend as a result?

Employing a similar rationale and approach, we then explore how Japanese popular attitudes are framed in response to escalation in the disputes between South Korea and China over Socotra Rock, which is submerged in the Yellow Sea, as well as the more conventional territorial dispute over Changbai/Paekdu mountain, which is actually situated between North Korea and China, but wholly claimed by both North and South Korea (Guo 2007).

Ultimately, our analysis of third-party popular perceptions in Northeast Asia will include analysis of Chinese opinions on tensions between South Korea and Japan over the Tokdo islets (known in Japan as Takeshima, and in the West as Liancourt Rocks), a dispute that has some parallels with Diaoyu/Senkaku. Preliminary investigations suggest that explicit connections between the Tokdo/Takeshima dispute and the Senkaku/Diaoyu one are rare in mainstream Chinese media and online. ${ }^{2}$ This is symptomatic of the strong control exerted by the state over the media and cyberspace in China, which complicates assessments of popular opinion on 'sensitive issues'. We limit our coverage of China here to a brief overview of online popular nationalism, before concentrating on the more comparable mediascapes and cyberspace ecologies of Japan and Korea that are the focus of this article.

\section{Popular Dynamics of Chinese Nationalism}

When the Chinese Communist Party (CCP) began its patriotic education campaigns in the 1990s, nationalism was conceived of as a reliable 
source of much needed legitimacy and popular support. However, the volatile nature of popular nationalism, particularly the virulent strain evident in Chinese cyberspace, has created unforeseen pressures for the government. The rise of popular nationalism has complicated the state's monopoly on foreign policy-making, for instance by challenging the strategy of 'hide and bide' through the 1990s and early 2000s, which was incompatible with the stridency of popular opinion. ${ }^{3}$ Popular nationalism is thus a double-edged sword, both a source of legitimation for continued authoritarian rule, and 'a means for the Chinese people to judge the performance of the state' (Zhao 2013: 541). The Party would prefer nationalism to be channelled and controlled like the regulated waters of a dam, but the strength of grassroots sentiments and the commercial imperatives that prevail in Chinese media and Chinese cyberspace make it difficult to turn on and off at will (Jiang 2012; Stockmann 2011). Furthermore, nationalism is not the sole prerogative of the state, and in many cases it is led by commercial interests exploiting market demand; in the population at large and particularly in the comparatively free conditions that pertain in Chinese cyberspace, nationalism 'sells'. The world of online gaming provides an example of how state and commercial actors operate cooperatively to leverage popular demand. When the Party accepted the popularity of gaming, particularly among the younger population, it seized on it as a pedagogical opportunity. Online games were declared 'cultural products' and the state made substantial investments in the industry so that 'patriotic online games became a joint enterprise between the Party-state and private companies' (Nie 2013: 508). In combination, state and commercial interests were highly effective in inculcating popular nationalist sentiments through online games such as the War of Resistance series where players take on the role of various Chinese forces fighting against the Japanese occupiers in various bloody scenarios. Such games appear to be particularly popular among the 'angry youth' (fenqing 愤青) that constitute one of the most stridently nationalistic cohorts. This demographic is also especially connected and active online (Sullivan 2014), responsible for much of the mobilization that periodically spills over into physical world demonstrations.

Yet, despite the rapid growth of the Chinese Internet population and fast-moving social media, the state has demonstrated the continuing capacity to contain popular nationalism. As Jessica Weiss (2014) shows in her analysis of state management of anti-foreign protests from 1985 to 2012, where prevailing diplomatic conditions and strategic context demands it, the state is able and willing to control anti-Japanese dem- 
onstrations, both in the physical world where its capacities are not in doubt, and online. The information order in cyberspace is facilitated by multiple layers of monitoring and control and reinforced by a sophisticated censorship regime and propaganda mechanisms. State control of the physical infrastructure of the Internet and a binding legal framework create a norm of self-censorship and self-regulation that ensures that commercial Internet companies do not act against the state's regularly updated strategic objectives. Thus, as Beijing sought to improve relations with Tokyo from 2006 to 2010, online petitions and mobilization of offline demonstrations were regularly and robustly restricted. The scale of this resolve was demonstrated on the eve of a sensitive anniversary in Sino-Japanese relations, when efforts in Chinese cyberspace to organize offline demonstrations were so tightly restricted that the Chinese term 'Diaoyu' was blocked, while 'Senkaku' evaded censorship (Han 2010). On other occasions, notably Japan's bid for a permanent seat on the UN Security Council in 2005 and nationalization of the disputed islands in 2012 , online and offline protests have been allowed to proceed.

Comparing anti-Japan protests over two decades, James Reilly describes a cyclical pattern in which 'a single inflammatory event can spread rapidly across a broad segment of the engaged public, stimulating online debates and activism that can spill over into the streets' (2014). Although such grassroots mobilization may initially be tolerated by the state and encouraged by commercial incentives related to a receptive public, the state's cost-benefit calculation changes over time. At the point that the state calculates that demonstrations may start to jeopardize domestic stability, long-term foreign policy objectives, trade relations, etc., the state's information control regime is engaged, controlling the tone of media coverage, censoring discussion and putting out counternarratives (Reilly 2012). Numerous scholars have noted how online and physical world protests can be useful as a safety valve allowing people to blow off steam, as a feedback mechanism alerting authorities to how strongly the public feels about an issue, and as a tool in internal power competitions to signal behaviour (Hasid 2012; Shen and Breslin 2010; Sullivan 2012; Weiss 2013). However, scholars have also identified how protests can spiral out of control, as was the case with the 1999 protests outside the US Embassy in Beijing following the NATO bombing of the Chinese Embassy in Belgrade. Nationalist causes can also mutate, with anger being redirected against the state. Goubin Yang observes that, 'as online protests against Japan indicate, online nationalist protests may open up new spaces for citizens to exert their discursive rights' (2009: 
56). In other cases, such as the protests against atrocities committed against ethnic Chinese in Indonesia in 1998, the state has been attacked for demonstrating insufficient patriotism (Hughes 2000).

\section{Korean Attitudes: Suspicion/fear of China and Resentment towards Japan}

Both China and Japan have intervened in the Korean peninsula. China's involvement in Korean affairs began very early, during the time of the Han dynasty (206 BC-220 AD). The Chinese invaded the proto-Korean kingdom of Gojoseon during the reign of Han Wudi and established four commanderies in 108 BC in what is now North Korea. Since then, the Chinese have periodically intervened both diplomatically and militarily in Korean internal affairs, the latest example being the Chinese military aid given to North Korea during the Korean War (1950-1953) (Chen 1994; Zhang 1995). Similarly, the Japanese continuously troubled Korea's southern border regions with their infamous Waegu/Wokou pirate raids and full-scale invasions (Toyotomi Hideyoshi's invasions, 1592-1598) and the Japanese occupation and colonization of Korea (1910-1945) (Beasley 1991). This long history of being on the receiving end of Chinese or Japanese military aggression has left a deep, innate and ever-present feeling of grievance among many Koreans towards their two powerful neighbours.

Some Koreans fear China's rising power and are suspicious of its intentions towards Korea. At the same time, they feel resentment towards Japan, which brutally colonized Korea in the early twentieth century (1910-1945) and still offends Koreans regularly with historical revisionism, the 'comfort women' issue in particular (Schellstede 2000), and territorial claims to Tokdo, which the Japanese call Takeshima. ${ }^{4}$ Tokdo and the comfort women are emotive issues that regularly inflame nationalist sentiments in Korea and, although they have little potential to cause a real military conflict between Korea and Japan, they have contributed significantly to the formation of pro-Chinese opinion among some segments of the Korean public in the case of the Senkaku/Diaoyu Islands dispute.

While it is highly likely that Japan is still viewed more negatively in Korea than China, at least among the general public, among the academic and policy making elite, China is now much more of a source of fear and suspicion. This fear was already apparent due to Communist China's military intervention and invasion of South Korea during the 
Korean War (1950-1953, in support of the Kim dynasty in North Korea and in opposition to the USA and South Korea). It was reignited in all sectors of Korean society, not just among the elite, because of the so-called Northeast Project (동북공정). The revisionist Chinese claims to what the Korean public regards as historical Korean states such as Goguryeo and Balhae (동북공정), ${ }^{5}$ over the past decade have sparked an emotional response among nationalistic Koreans and heightened anti-Chinese sentiment in Korea. The claims to Goguryeo (also known as Koguryo) and Balhae are part of China's concerted effort to strengthen its historical-territorial claims on its borders (Duara 1996; Townsend 1996; Wang 2001; Wang 2012) and to allay its own internal security concerns (Chen 2012; Gries 2005). This assertiveness has offended the vast majority of the South Korean public. ${ }^{6}$

As a corollary to this renewed anti-Chinese sentiment, one of the bestknown narratives of Korea's historic struggle against China - the wars fought by Goguryeo in the seventh century against the Sui dynasty (589618 AD) and then the powerful Tang dynasty (618-907 AD) - have been re-emphasized to highlight Korean resistance to Chinese aggression. This is reflected by the immense popularity of period dramas such as the Korean Broadcasting System's (KBS) Dae Jo Yeong (2006-2007), which glorified Goguryeo's heroic resistance to Tang China and was produced with the deliberate aim of countering China's historical revisionism. ${ }^{7} \mathrm{~A}$ reflection of the equally, if not more, virulent anti-Japanese sentiment in Korea is shown by the success of the KBS period drama Immortal Yi Sun Shin, which celebrated the life of Korea's foremost military hero, Admiral Yi Sun Shin, who defended Korea against Japanese invaders in the sixteenth century.

Many in South Korea, especially the policy planning elite, fear that China's historical revisionism (the so-called Northeast Project) is merely a smokescreen designed to establish historical claims to territory in North Korea in the same way that Tang Taizong used 'history' to justify Tang occupation of Goguryeo territory (Shin 2012). For instance, Bak Changhee of Gukbang University argues that China has traditionally viewed the Korean peninsula as its sphere of influence and will intervene to protect what it sees as its vested interests in North Korea (Park 2012: 221-222). He also asserts that China's ultimate strategic goal is to expand its power further into the Korean peninsula, separate South Korea from its alliance with the USA and establish a pro-Chinese government in the whole of the peninsula (Park 2012: 228). Such fears of Chinese aggression must be taken into consideration when we examine Korean 
attitudes, especially academic attitudes towards the islands dispute between China and Japan.

Chinese support for North Korea and the perceived snub of South Korea following the sinking of the South Korean warship Cheonan in 2010, have only heightened such fears. Yi Sanghyun from the ministry of foreign affairs argues that China's rise and continued support for North Korea's Kim dynasty represents a potential threat to South Korea's security. He also argues that China's ambition is to turn Korea into a buffer zone and dominate the East China Sea (excluding other powers such as the USA from East Asian waters), and that China's so-called 'peaceful rise' might not be so peaceful after all (Yi 2012: 277-278). Yi further asserts that China's recent behaviour towards Korea conceals a desire to view Sino-Korean relations in the light of the tributary relations that existed between Korea and China in the pre-modern, 'feudal' era, i.e., that it is an expression of arrogance. A fear of Chinese maritime expansion and ambitions towards Ieodo (이어도) and Korea's Exclusive Economic Zones (EEZs) in the East China Sea have also been raised by academics engaged in Korean naval defence planning. Cha Do Hee, for instance, emphasizes the fact that the USA and China are engaged in a power struggle over naval hegemony in East Asia. Strengthening the US-Korea military alliance and expanding Korean naval capacity are needed to defend Korea's maritime borders, trade routes and economic interests in the East China Sea (which includes the disputed islands of Senkaku/Diaoyu) and to counter China's growing expansionist ambitions (Cha 2012; Yi 2007).

\section{The Senkaku/Diaoyu Islands Dispute in Korean Media and Blogs}

The territorial dispute between Japan and China over the Senkaku/Diaoyu Islands has been followed with keen interest by the South Korean media, bloggers and international relations experts. This is primarily because its peaceful resolution or violent implosion may have significant ramifications for possible future handling by South Korea of its own territorial disputes with both Japan (Tokdo dispute) and China (Ieodo, Baekdusan and the Gando disputes). Korean attitudes concerning the dispute between China and Japan are very diverse. They range from those who express sympathy for China (usually those among the general public whose political sympathies are left-aligned or have strong antiJapanese sentiments) to those who vouch for careful, guarded neutrality 
or advocate anti-Chinese and pro-Japanese policies (usually those who are on the right wing of the political spectrum and are hostile to China's perceived territorial ambitions in East Asia). These differing opinions and attitudes among Koreans are inseparably linked to Korea's historical relations with both countries, memories of which can still inflame nationalist sentiments within Korea. These historical memories of past grievances (directed at both Japan and China, but more so at Japan), when coupled with existing territorial disputes and economic and strategic concerns, produce a very complex and varied reaction among the Korean public and the academic community. All these aspects of the Korean reaction to and representation of the disputes between China and Japan will be explored below.

As noted earlier, the majority of the Korean policy planning elite and international relations experts (who generally tend to be more conservative than the mass media and netizens) are more concerned about the present threat/pressure coming from China than about past historical grievances towards Japan. Many are of the opinion that Korea should give support to the maintenance of the status quo with Japan in possession of the disputed islands, while maintaining a show of neutrality to avoid antagonizing China. An outright Chinese victory in the affair would lead to the domination by China of the vital sea lanes through which the majority of Korea's trade traffic and energy supplies pass. ${ }^{8}$

However, the anti-Japanese sentiments generated by Japan's repeatedly provocative behaviour with regard to the comfort women issue and also the continuing Tokdo dispute with Japan made outright support for Japan in 2012 a very unappealing course of action for the Korean public in general. ${ }^{9}$ The Korean media and Internet bloggers repeatedly pointed out Japan's hypocrisy in claiming territory currently controlled by Korea, yet denying China's historical claims to territory controlled by Japan. In other words, they suggested that Japan's position vis-à-vis China is similar to Korea's position in relation to Japan. This was often accompanied by the hope that the resolution of the Senkaku/Diaoyu Islands dispute would be peaceful and yield useful precedents for Korea to utilize in its own territorial dispute with Japan. ${ }^{10}$ Most of the Korean media ${ }^{11}$ and bloggers ${ }^{12}$ eventually adopted a semi-neutral stance, taking jibes at the Japanese for their double standards when it comes to territorial disputes, but not supporting China either, since Korea is comfortable with neither China nor Japan. Policy planners and academics in general advocated a careful, measured response to the dispute between Japan and China while making sure to pick up any developments that might 
be of use in future negotiations with China and Japan over Korea's territorial disputes with both powers.

However, political divisions within Korea meant that there was, as usual, a pro-Chinese minority that attempted to utilize the anti-Japanese feeling in Korea and resulting sympathy, albeit brief, for China among the Korean public (largely due to anger towards Japan over Tokdo), to advance China's interests. They view China's interests as matching their own political goals of advancing rapprochement with North Korea with Chinese aid and moving Korea out of America's sphere of influence (Gang and Park 2012). The left-aligned newspapers, bloggers and netizens in Korea, who traditionally favoured Communist China and appeasement of North Korea, therefore represented the islands dispute in a decidedly pro-Chinese light, casting the Japanese as imperialists who had stolen Chinese territory just as they now seek to steal Korean territory. ${ }^{13}$

Ohmy News, a radical left-wing newspaper, emphasized that Japan stole the islands from China while China was weak in the nineteenth century and then held on to them with US aid..$^{14}$ Hankyoreh (한겨레신 문), another left-wing newspaper, published an article titled 'Are the Diaoyu Islands becoming the second Manchuria', hinting thereby that Japanese occupation of the islands is as illegal as the Japanese takeover of Manchuria was in the 1930s, thereby faithfully repeating the views of newspapers in the People's Republic of China on the issue. ${ }^{15}$ Similarly, left-wing bloggers openly claimed that the islands belong to China and that the only reason that Japan can indulge in disputing ownership of Tokdo and the Diaoyu Islands with both Korea and China simultaneously is American 'imperialist' support. Thus, while fanning anti-Japanese sentiments they also sought to trigger anti-American sentiments, while putting a gloss of neutrality on their views by advocating that Korea do nothing in support of either party. This was clearly a message directed at refuting the views of conservatives who sought more active cooperation with Japan and the USA against China in the East China Sea. ${ }^{16}$

More right-wing newspapers, in contrast, have shown ambiguous attitudes towards the dispute. The right-wing daily Dong-A Ilbo loudly denounced Japan's militarist past as part of the denunciation of Japan's territorial claims on Tokdo and historical revisionism on the comfort women issue. ${ }^{17}$ However, with regard to the islands dispute, it was more concerned about the economic fallout from the Sino-Japanese conflict than about the issue of who deserves Korea's support. ${ }^{18}$ The conservative Chosunilbo also vocally denounced Japanese aggression on the Tokdo issue and warned that if Japan continues to veer to the far right it will 
fall into ruin as it did during the Second World War. It added further that Japan's actions with regard to the Tokdo and Senkaku Islands disputes show that Japan is still dreaming the delusional militaristic vision of expansion that brought Japan low in the past. ${ }^{19}$ However, the newspaper also soon balanced this sharp rebuke of Japan with caution about supporting China on the issue. The newspaper reminds viewers that the Chinese claims in the East China Sea and the seas off the coasts of Okinawa already may infringe on the territorial rights and economic interests of Korea to the south. ${ }^{20}$

Joongangilbo, another conservative daily, went so far as to claim that Japan's lurch to the right is reaching dangerous levels and that Japan is on its way to developing a nuclear weapons program that is threatening to Korea. ${ }^{21}$ However, in blogs associated with the newspaper, China was also vehemently denounced for its arrogant attitude and territorial ambitions in the East China Sea, the ultimate goal of which, it was claimed, is to create a new tributary system in its favour in East Asia. ${ }^{22}$ Other conservative or centre-right newspapers tended to emphasize more the fact that this territorial dispute between China and Japan has the potential to infringe also on Korea's territorial claims and EEZs in the East China Sea and Sea of Japan. ${ }^{23}$

Because of the similarities between this dispute and the Tokdo dispute between Korea and Japan, the Korean blogosphere has featured some interesting commentaries on the issue. Although it is difficult to quantify, at the outbreak of the crisis in 2012, the dominant response to the dispute among Korean netizens who left comments on blogs and newspapers online, was support for China and hatred for Japan, which was disputing Tokdo with Korea. However, by the time bloggers started analysing the situation in detail, the mood had palpably shifted. Some blogs placed the dispute within the context of other territorial disputes across East Asia, mostly involving China and Japan, and adopted a dispassionate commentary approach. ${ }^{24}$ Some were even surprisingly hostile to China and accused the Chinese government of using the issue to hide internal problems and justify its naval build-up, which is a threat to Korea. ${ }^{25}$

Still others advocated caution and warned against openly supporting China on the issue, despite dislike of Japan, because Korea's position vis-à-vis Japan on Tokdo is actually more similar to Japan's vis-à-vis China, than China's vis-à-vis Japan. If Japan were to lose the Senkakus on grounds proposed by China, Korea may be placed at a disadvantage, if disputes escalated over Tokdo with Japan, on those same grounds. 
People were reminded that Korea has ongoing territorial disputes with China as well. ${ }^{26}$ Many were simply neutral on the issue, noting the huge economic and strategic benefits of controlling these islands, which is driving both China and Japan to contest them, and advised that Koreans simply be observant about the arguments employed by both sides in advancing their claims. ${ }^{27}$ Some were, however, more emotive and expressed a common feeling of sorts with the Chinese because of Korea's problem with Japan on the Tokdo issue and advocated support for China on the issue. ${ }^{28}$

As time passed and disputes with China returned to the attention of Koreans, the initial warmth of Korean feeling towards China, which was perceived to be engaged in the same struggle as Korea against the aggressions of Japan, slowly cooled. The majority of newspaper editorials and blogs (including reader commentaries) swung in the direction of caution and the urge to pick sides in the dispute quickly vanished. The advice of most bloggers and academic experts was to keep a level head, be alert about what the dispute will mean for Korea and to think strategically for the national benefit. Korea, as usual stuck in the middle between Japan and China, has its share of pro-Japanese (less vocal) and pro-Chinese (more vocal) advocates. However, the vast majority in the middle now seem to favour a much more nuanced and sensible approach to the dispute, which is in line with the caution displayed by the rest of the international community on the issue.

\section{Socotra Rock: A Sino-Korean Bone of Contention}

The dispute between China and South Korea over Socotra Rock involves complex historical, nationalistic, territorial, administrative, economic and defence issues. Interestingly, Socotra Rock remains relatively unknown to the outside world -including Japan. Indeed, one Japanese netizen has frankly admitted that Socotra Rock is 'unfamiliar to [Japanese] ears'.$^{29}$ This perhaps necessitates a brief introduction. Socotra Rock (lat. $125^{\circ} 10^{\prime} 56.81^{\prime} \mathrm{E}$; long. $32^{\circ} 07^{\prime} 22.63^{\prime} \mathrm{N}$ ) is located in the Yellow Sea, some 150 kilometres southwest from South Korea's Marado Island, and some 250 kilometres northeast from China's Haijiao Island (the nearest Japanese island is located only 275 kilometres away). Known in Korean as Ieodo (or Parangdo) and in Chinese as Suyan, it is not an island but a submerged coral reef, which, at low tide, is 4.6 metres beneath the ocean's surface. Centuries-old Korean legends caution that sailors and fishermen who see the reef will never return home; the Brit- 
ish merchant vessel, Socotra, which spotted the reef in 1900 (and which presumably remained ignorant of Korean legends), not only returned to London but also bestowed upon the reef its English-language name, Socotra Rock.

Japan's victory in the Russo-Japanese War in 1904-1905 ensured, over the ensuing decades, that the Imperial Japanese Navy maintained control of the waters surrounding Socotra Rock. This remained the case until Japan's defeat in World War II. Thereafter, Socotra Rock bubbled beneath the surface of Sino-South Korean relations. In 1952, even as the Korean War raged, the South Korean government promulgated the so-called Syngman Rhee line. This line specifically included Socotra Rock within Korean territorial waters. The People's Republic of China declined to recognize this line. South Korea in the 1990s ignored Chinese objections and began building a weather station on Socotra Rock.

Not until completion of the weather station did Socotra Rock become a hot-button issue in Sino-South Korean relations. Technically speaking, the dispute is not a territorial issue. According to the United Nations Convention on the Law of the Sea, a submerged reef - such as Socotra Rock - cannot be considered national territory. Yet, in seemingly open defiance of the United Nations, the South Korean government insists that Socotra Rock is clearly South Korean territory. At the very least, South Korea maintains that it will not budge from the basic insistence that Socotra Rock falls within its own EEZ. The Chinese government, which also claims that Socotra Rock lies within its EEZ, has registered its 'opposition' to 'unilateral [South Korean] actions' on Socotra Rock (Sawa 2007). In March 2012, a Chinese official hinted at Chinese unilateralism concerning Socotra Rock. The official sparked a diplomatic row when he publicly noted that, because Socotra Rock is located in Chinese waters, it is most certainly Chinese.

It is difficult to characterize Japanese responses to this Sino-South Korea diplomatic row. Some have expressed surprise. 'Territorial disputes are not only a Sino-Japanese and Korean-Japanese issue', commented the online news source, News U.S. ${ }^{30}$ The vastly more reputable Newsweek carried an article with a similar sentiment; it noted that China's seemingly 'endless' appetite encompassed 'not just Okinawa'. ${ }^{31}$ Such surprise is perhaps understandable. On the one hand, Socotra Rock (as already noted) remains largely unknown in Japan. On the other hand, the Japanese are preoccupied with their own nation's manifold territorial disputes, including those involving not only China and South Korea but also Russia, North Korea and Taiwan. 
Some Japanese see in the Socotra Rock dispute confirmation of what they regard as Chinese expansionism. News U.S. put it simply: 'China's plan to conquer East Asia has at last begun to gain momentum'. ${ }^{32}$ One netizen voiced a similar notion: 'China is showing its limitless greed'. ${ }^{33}$ One blogger reckoned that, because the colonial powers (including Japan) had sliced China up in the nineteenth and early twentieth centuries, China now 'wants to expand its defensive line as far as possible'. That defensive line, according to this blogger, extends far beyond the Asian mainland and most certainly includes Socotra Rock, principally because the Chinese want to fight the United States in the Pacific. ${ }^{34}$

Japanese bloggers do not spare South Korea in their analysis of the dispute over Socotra Rock. At least one blogger has pointed to the discrepancy between the South Korean territorial claim over Socotra Rock and the UN's insistence that a sunken reef cannot be national territory. ${ }^{35}$ Another pointed to the South Korean government's express desire for 'sincere' discussions with China - and questioned then president Lee Myung-bak's own sincerity. As evidence, this blogger pointed to Lee's rejection of then Japanese prime minister Noda Yoshihiko's letter concerning the Liancourt Rocks. ${ }^{36}$ It should also be acknowledged that Japan's fringe-dwelling extreme right wing takes delight in the Sino-South Korean dispute over Socotra Rock; the extreme right tends to be derisive in its treatment of South Korea. One example should suffice: China is 'conscious that it is lying' about its claim over Socotra Rock, while South Korea is a 'paranoid, compulsive liar'. The blog concludes by noting that, if China continues to insist that even Okinawa Prefecture is Chinese territory, then Korea's fate is all but sealed. It predicts the arrival of the day when the Korean peninsula again becomes a Chinese 'tributary'. ${ }^{37}$

One armchair strategist believes that Japan and South Korea could 'clash' militarily over Takeshima/Tokdo and that such a Japanese-South Korean clash would provide China with a 'good opportunity to attack and occupy Socotra Rock'. Our erstwhile armchair strategist noted that South Korea would then find itself fighting great powers on either side, and concluded that Poland's fate at the hands of Germany and the Soviet Union in 1939 could well revisit South Korea. Such thinking sparked comments from any number of other armchair strategists. 'Has China realized that is not in its best interests to go to war with Japan?' asked one. Another lamented the Japanese government's unwillingness to take a similarly 'hard-line stance' in its dealings with its neighbours. ${ }^{38}$

There are also those who would welcome Japan's active involvement in the dispute over Socotra Rock. The Rock evidently lies within 
Japan's Air Defence Identification Zone (ADIZ), which at the very least means that planes flying thereover must first gain Japan's approval. This includes the South Korean Air Force. One self-proclaimed expert in Japanese-Korean relations wrote in October 2012 that the South Korean Air Force had sought and received Japan's permission to fly over Socotra Rock 17 times that year. ${ }^{39}$ Some bloggers emerged convinced that Socotra Rock is indeed 'Japanese territory'. Almost invariably, this sparked the imaginations of the Internet's wannabe diplomats. 'If you swap Takeshima', wrote one, 'Japan will recognize [South Korea's claim to Socotra Rock]'.40

\section{The Changbai/Paekdu Dispute through Japanese Eyes}

Japanese perceptions of the Sino-Korean dispute over Changbai/Paekdu Mountain are equally fragmented and complex. Changbai/Paekdu Mountain's volcanic summit cups a crater lake on the Sino-North Korean border. Chinese regard Changbai (Chinese name) Mountain as very much part of Manchuria; Koreans see Paekdu (Korean name) Mountain as the birthplace of their culture and also remember it as the nerve centre of resistance to Japan's colonial rule over their peninsula during the early twentieth century. North Korean leader Kim Jong-il was, moreover, (reputedly) born on Changbai/Paekdu Mountain, and the North Korean government regards it as 'sacred territory' (Kin 2003).

Let us begin with a review of academic views of the dispute. Akizuki Nozomi (2010) has argued that the Changbai/Paekdu issue (like other territorial issues in the region) has arisen at least partly because of the difficulties inherent in applying modern international law to areas that until the 1800s operated under a very different world system. Akizuki has also reminded readers that Japan sought definitive answers to territorial questions in the early twentieth century. In this regard, he has drawn readers' attention to Shinoda Jisaku's groundbreaking 1938 study of the Sino-Korean border, which asserted unequivocally that Changbai/Paekdu Mountain had long been Korean territory. Kyoto University's Nakanishi Terumasa (2013) has written of a 'new Cold War', which he believes will characterize Sino-Japanese relations. He argues that the Changbai/Paekdu issue bodes well for Japan, insofar as it should smooth the way for closer Japanese-Korean friendship, forged in opposition to China.

One suspects that Nakanishi has gained a little more traction with his essay than has Akizuki with his strictly academic text. One Japanese 
blogger registered incredulity with South Korea's claim over Changbai/ Paekdu Mountain. He notes two points. First, North Korea maintains near silence over the issue. Second, Changbai/Paekdu Mountain is physically very far removed from South Korean territory. He argues that South Korea had 'unilaterally' created this problem, and contrasts the South Korean stance with that of North Korea's 'silence'. This silence he attributes to the fact that China is North Korea's only 'lifeline' and that North Korea feels utterly unable to 'complain' to China. He concludes that Japan should 'learn' from China, and come out strongly against South Korean attempts to change the name of the Sea of Japan. ${ }^{41}$

Another Japanese netizen has registered his surprise at this territorial dispute. He acknowledged that he had long known of a widespread Chinese 'backlash' against the Koreans. In this regard, he pointed to a Chinese conception of the Koreans as having failed to develop their own culture and having simply 'stolen' Chinese culture. He regarded the Changbai/Paekdu issue as evidence that Sino-Korean disputes go beyond the cultural realm and include territorial problems. ${ }^{42}$

Many Japanese bloggers tend to view the Changbai/Paekdu issue through the prism of territorial issues that involve Japan. One has asked whether any 'demonstration movements' (similar to those that bedevil Sino-Japanese relations) have arisen in China over the Changbai/Paek$\mathrm{du}$ issue. Another concludes that the Chinese 'make their own maps' and therefore dispute territory with virtually all of their neighbours, including Japan. Yet another states simply that the Chinese are the 'same as a band of robbers'. Having read these (and other) comments, another blogger concluded that China is bent on expansion, then veered away from the Changbai/Paekdu issue to note that Chinese citizens living in Japan may well be 'preparing for an internal [Japanese] revolt', which would presumably assist China in its claims over the Senkaku Islands and even Okinawa Prefecture. ${ }^{43}$

\section{Conclusion}

Japan and South Korea are both wealthy industrial powerhouses that have much more in common with each other than with China, and are both strategically allied with the USA. Yet, although the political establishments in both countries might see China as a constant threat, Korea and Japan still popularly view each other with suspicion. By contrast, popular perceptions of the China threat in either country can be swayed by escalation of territorial disputes these two US allies still have with 
one another. In that sense, it is hardly surprising that the famous rapport between President George W. Bush and Prime Minister Junichiro Koizumi worked to embolden Japanese 'nationalists and reactionaries', much to the chagrin of both the South Korean and Chinese leadership (Calder 2008).

In the realm of popular sentiment, Korea's ongoing historical and territorial disputes with both China and Japan disallow clear-cut solidarity with either party or explicit analogies with the dispute between China and Japan, because both powers are regarded as being dangerous to South Korea and not trusted by any means. The escalation of the Japan-China dispute in 2012, which immediately followed South Korea's most recent spat with Japan over Tokdo, temporarily led to more positive public opinion towards China, but quickly gave way to more balanced analysis of the issue. If the dispute was to recur now in the midst of North Korea's threats against South Korea, support for Chinese claims would likely be ambiguous. This is in part due to China's continued reluctance to rein in its 'client' state, (given the perception that North Korea is merely a 'vassal' or worse a 'puppet' of China), which also pricks the nationalist pride of many South Koreans. The academic community and policy making elite in South Korea favour aligning Korea with the USA and Japan against Chinese naval expansion in the East and South China Seas. However, deep political divisions between the political left (which favours China and North Korea) and the right (which favours the USA and Japan) and the continuing question of Tokdo are likely to prevent South Korea from effectively coordinating a common response with Japan against China in the foreseeable future.

Similarly, in view of the Takshima/Tokdo dispute, Japanese bloggers hardly spare South Korea in their analysis of the dispute over Socotra Rock. Their respective alliance with the USA notwithstanding, many Japanese appear concerned about rapprochement between China and South Korea. However, others in Japan's far right might actually revel in escalation of the Socotra or Changbaishan disputes as a form of teaching South Korea a 'lesson' in middle-power hubris. In the background lingers much phobia about putative Chinese designs on Okinawa or mainland Korea, putative Korean designs on China's northeast and bitter memories of Japan's wartime brutality. While identifying popular suspicion and resentment in Northeast Asia is a confirmatory finding, one issue this article points to that deserves further attention is growing unease about South Korea's delicate balancing act in the face of China's rise. Economically (and culturally) close to China, and quite often at 
loggerheads with Japan, South Korea's experience of the 1980s-1990s is highly germane to China's ongoing reforms. South Korea is also a US ally whose conduct as a middle power is important to monitor in the context of deteriorating Sino-Japan relations and American re-balancing.

Niv Horesh is Reader in Chinese Studies and Senior Fellow at the China Policy Institute, the University of Nottingham.

Email:niv.horesh@nottinham.ac.uk

Hyun Jin Kim is Lecturer at the School of Historical and Philosophical Studies at the University of Melbourne.Email:kim.h@umelb.edu.au

Peter Mauch is Senior Lecturer at the School of Humanities, University of Western Sydney. Email:p.mauch@uws.edu.au

Jonathan Sullivan is Associate Professor and Deputy Director, China Policy Institute, University of Nottingham.

Email: jonathan.sullivan@nottingham.ac.uk,orTwitter:@jonlsullivan

\section{NOTES}

1 This article derives from an international collaborative project focusing on contending national identities across Asia that has been initiated and led by Niv Horesh since 2010. The first research output of this project appeared in Kim, Mauch and Horesh (2012).

2 For example, there are no articles in the official Renmin Ribao (People's Daily) that explicitly discuss the Tokdo and Diaoyu disputes in tandem. For an academic treatment, see Li and Qiu (2010).

3 For an example of the stridency of popular nationalism online, see Chase's (2011) analysis of Chinese reactions to UNESCO's decision to make the Gorguryeo Tombs a world heritage site.

4 There is an immense amount of literature on this dispute in Korean and in other languages. This territorial dispute, which South Korea refuses to acknowledge officially since Tokdo is de jure and de facto part of Korea, continues to poison Korea-Japan relations.

5 This highly publicized and acrimonious dispute between China and Korea over ancient history is mirrored by an equally acrimonious disagreement over more recent history between Korea and Japan, which receives treatment in Kimijima (2000).

6 For excellent analyses of the dispute over ancient history between China and South Korea and the negative effects of nationalist indoctrination in both countries, see Yi (2001) and Yi (2005).

7 See http:/ / bit.ly/1iqf3em (accessed 26 September 2013).

8 The more radical exponent of this view is Gang (2012); however, there is a general wariness among the policy planning elite of South Korea about China's naval expansion in the East and South China Seas, which they feel can develop into a long-term 
Niv Horesh, Hyun Jin Kim, Peter Mauch and Jonathan Sullivan

threat to Korea's economic and strategic interests. A strengthening of the alliance and cooperation with the USA and Japan as a means of countering Chinese naval expansion is the dominant thinking among policy planners in Seoul (Jeong 2012).

9 Anti-Japanese sentiment generated by yet another spat with Japan over Tokdo in 2012 shortly before the dispute over the Senkaku/Diaoyu Islands flared up again between China and Japan, influenced the views of the South Korean mass media and also bloggers towards the dispute between China and Japan.

10 For instance, http:/ / bit.ly/1is2KyF; http://bit.ly/1bqZjDg; http://bit.ly/1b21umr (last viewed 26 September 2013). The reader commentaries/responses to this blog's neutral approach and call for moderation were positive, with all commentaries emphasizing the negative economic consequences for Korea should the situation escalate.

11 Every South Korean newspaper entry/editorial on the Senkaku-Diaoyu Islands dispute prior to 26 September 2013 has been accessed and analysed for the purposes of this article.

12 Similarly, every Korean blog that discussed the crisis prior to 26 September 2013 has been accessed and analysed. Unfortunately there is simply no way of quantifying the extent to which these blogs and newspaper entries reflect Korean public opinion, since no polls were taken to determine accurately how the general public views the crisis and the belligerents involved. If, however, the representation in mass media (in this case newspapers and blogs) is taken as a reflection of the way in which the situation is presented to the Korean general public, their overall impact on public opinion is quite apparent. Therefore, a comprehensive analysis of these blogs, reader commentaries and newspapers is a useful exercise in assessing public opinion in the absence of concrete polling data.

13 See http:/ / bit.ly/1ipXkDS (accessed 26 September 2013).

14 See http:/ / bit.ly/1eTWcoa (accessed 26 September 2013).

15 See http:/ / bit.ly/1dqrAcS (accessed 26 September 2013).

16 See http:/ / bit.ly/1ipXkDS (accessed 26 September 2013).

17 See http:/ / bit.ly/1b22kiR (accessed 26 September 2013; http://bit.ly/1cUMghG, accessed 26 September 2013).

18 See http://bit.ly/1b22tTr (accessed 26 September 2013; http://bit.ly/1buDGVY, accessed 26 September 2013).

19 See http:/ / bit.ly/N2sqYs (accessed 26 September 2013).

20 See http:/ / bit.ly/1ipZeUX (accessed 26 September 2013).

21 See http:/ / bit.ly/LyABKc (accessed 26 September 2013).

22 See http:/ / bit.ly/1dqs8Qa (accessed 26 September 2013).

23 See http:/ / bit.ly/1iq04RD (accessed 26 September 2013).

24 See http://bit.ly/1at3hA7; http://bit.ly/1kTiD1Z (both accessed 26 September 2013).

25 See http:/ / bit.ly/1is4Gan (accessed 26 September 2013).

26 See http:/ / bit.ly/1c3LHxS (accessed 26 September 2013).

27 See http:/ / bit.ly/Mt9fpD; http:/ / bit.ly/1is4Xdy; http:/ / bit.ly/1g1ZmbE; http:/ / bit.ly/1fuOu5A (all accessed 26 September 2013).

28 See http:/ / bit.ly/1c3Mjn9; http:/ / bit.ly/1c3MkHE; http:/ / bit.ly/1b23Kdi; http:/ / bit.ly/Mt9z7N; http://bit.ly/1c3MvCR; http://bit.ly/1b240ZD (all accessed 26 September 2013).

29 See http:/ / bit.ly/11AHZ8H (accessed 23 August 2013).

30 See http:/ / bit.ly/11AHZ8H (accessed 23 August 2013).

31 Newsweek Japan, 'Okinawa dake ja nai, Chūgoku no Hatenaki Sendo Ego', [It's not just Okinawa, China's infinite territorial ego], 21 January 2013, http:/ / bit.ly/1brbKPs 
(accessed 2 August 2013).

32 See http:/ / bit.ly/11AHZ8H (accessed 23 August 2013).

33 See http:/ / bit.ly/1fQYpnM (accessed 2 September 2013).

34 See http:/ / bit.ly/1eU1ujz (accessed 28 August 2013).

35 See http:/ / bit.ly/1is8jND (accessed 24 July 2013).

36 See http:/ / bit.ly/1iq93SR (accessed 1 September 2013).

37 See http:/ / bit.ly/1g25uRc (accessed 1 August 2013).

38 See http:/ / bit.ly/1nao3oy (accessed 31 July 2013).

39 See http:/ / amba.to/1dqvp1R (accessed 15 July 2013).

40 See http:/ / bit.ly/1iqaoZN (accessed 29 August 2013).

41 See http:/ / bit.ly/1b29dkf (accessed 19 August 2013).

42 See http:/ / bit.ly/1jfMwLT (accessed 13 August 2013).

43 See http:/ / bit.ly/1eU5107 (accessed 29 August 2013).

\section{REFERENCES}

Akizuki, Nozomi 2010. 'Sekai Chitsujo no Henyo to Kokka: Mankoku Koho no Juyo to Chuka Shisutemu' [Acceptance of International Law in East Asia: Modernization, Sovereign State, and China's Traditional Order], Meiji Gakuin Daigaku Kokusai Gakubu Fuzoku Kenkyujo Nenpo, Meiji Gakuin University Institute for International Studies Annual Research Report, 13: 3-16.

Beasley, William 1991. Japanese Imperialism 1894-1945. Oxford: Oxford University Press.

Calder, Kent 2008. 'Critical Junctures and the Contours of Northeast Asian Regionalism'. In East Asian Multilateralism: Prospects for Regional Stability, edited by K. Calder and F. Fukuyama, pp. 15-39. Baltimore: Johns Hopkins University Press.

Cha, Do-Hwe 2012. 동아시아 미-중 해양패권 쟁탈전: 미-중 해양력 세력전이와 천암 함 피격사건을 중심으로 [The US-China Rivalry over Naval Hegemony in East Asia: The Transfer of Naval Power Between the US and China with a Special Focus on the Attack on the Cheonam]. Seoul: Book Korea.

Chase, Thomas 2011. 'Nationalism and the Net: Online Discussion of Goguryeo History in China and South Korea'. China Information 25 (1): 61-82.

Chen, Dingding 2012. 'Domestic Politics, National Identity, and International Conflict: The Case of the Koguryo Controversy'. Journal of Contemporary China 21 (74): 227241.

Chen, Jian 1994. China's Road to the Korean War: The Making of the Sino-American Confrontation. New York: Columbia University Press.

Duara, Prasenjit 1996. 'De-constructing the Chinese Nation'. In Chinese Nationalism, edited by J. Unger, pp. 31-55. Armonk, NY: M.E. Sharpe.

Fogel, Joshua 2010. Articulating the Sinosphere: Sino-Japanese Relations in Space and Time. Cambridge, MA: Harvard University Press.

Gang, Hyo-Baek 2012. 중국의 습격: 류큐로 보는 한-중-일 해양 삼국지 [China's Surprise Attack: The Three-Way Struggle Between Korea, China and Japan with a Focus on the Ryukyu Islands]. Seoul: Human \& Books.

Gang, Jung-Goo, and Gi-Hak Park 2012. G2시 대 한반도 평화의길 [The Road to Peace for the Korean Peninsula in the G2 Era]. Pyonghwa-Tongil Yeonguso [Research Institute for Peaceful Unification]. Seoul: Hanul.

Gries, Peter 2005. 'The Koguryo Controversy, National Identity, and Sino-Korean Relations Today'. East Asia 22 (4): 3-17.

Guo, Rongxing 2007. Territorial Disputes and Resource Management: A Global Handbook. 
Niv Horesh, Hyun Jin Kim, Peter Mauch and Jonathan Sullivan

New York: Nova Science.

Han, Han 2010. 'Protect the [Unacceptable Input]', 12 September 2010. In This Generation: Dispatches from China's Most Popular Blogger, translated and edited by Allen Barr, pp. 182-184. London: Simon Schuster.

Hasid, Jonathan 2012. 'Safety Valve or Pressure Cooker? Blogs in Chinese Political Life'. Journal of Communication 62 (2): 212-230.

Hughes, Christopher 2000. 'Nationalism in Chinese Cyberspace'. Cambridge Review of International Affairs 13 (2): 195-209.

Jeong, Cheol-ho 2012. 미국과 중국의 동아시아 해양전략과 한국의 해양안보: 미, 중 간의 남중국해 해양통제권 경쟁과 갈등의 영향 [The East Asian naval strategy of the US and China and Korea's maritime security: The effect of the competition and struggle between the US and China over control of the South China Sea]. Seongnam: Sejong Yeonguso.

Jiang, Ying 2012. Cyber-Nationalism in China: Challenging Western Media Portrayals of Internet Censorship. Adelaide: University of Adelaide Press.

Kim, Hyun Jin, Peter Mauch and Niv Horesh 2012. 'Seoul Searching: The History, Politics and Prejudice behind the Re-naming of Korea's Capital in Chinese'. Provincial China 4 (1): 1-26.

Kin, Ki-san. 2003. Kuhaku no Kita Chosen Gendaishi: Pekutosan o Utta Kim Il-sung [The Void in North Korea's Modern History: How Kim Il-Song Sold Off Changbaishan]. Tokyo: Shinchosha.

Kimijima, Kazuhiko 2000. 'The Continuing Legacy of Japanese Colonialism: The Japan-South Korea Joint Study Group on History Textbooks'. In Censoring History: Citizenship and Memory in Japan, Germany, and the United States, edited by L. Hein and M. Selden, pp. 203-225. Armonk, NY: M. E. Sharpe.

Lary, Diana 2010. The Chinese People at War. New York: Cambridge University Press.

Li, Mingjie and Qiu Jun 2010. '韩国处理独岛争议措施对我国维护钓鱼岛主权的启示' [South Korea's Effective Handling of the Tokdo Dispute Can Provide Lessons for China's Campaign to Protect Its Sovereignty in Diaoyu]. Haiyang kaifa yu guanli [Ocean Development and Management] 27 (10): 58-61.

Nakanishi, Terumasa 2013. Semarikuru Ni-Chu Reisen no Jidai: Nihon wa Daigi no Hata o Kakageyo [The Impending Era of Sino-Japanese Cold War: Fly the Flag, Japan!]. Tokyo: PHP Shinsho.

Nie, Annie 2013. 'Gaming, Nationalism, and Ideological Work in Contemporary China: Online Games Based on the War of Resistance Against Japan'. Journal of Contemporary China 22 (81): 499-517.

Park, Chang-Hee 2012. '북한 급변사태와 중국의 군사개입' [Crisis in North Korea and China's Military Intervention]. In한반도 분쟁과 중국의 개입 [Conflict in the Korean Peninsula and China's Intervention], edited by J. S. Lee and S. H. Jo, pp. 221-251. Seoul: Sunin.

Reilly, James 2012. Strong Society, Smart State: The Rise of Public Opinion in China's Japan Policy. New York: Columbia University Press.

Reilly, James 2014. 'A Wave to Worry About? Public Opinion, Foreign Policy and China's Anti-Japan Protests'. Journal of Contemporary China 23 (86): 197-215.

Rose, Caroline 2004. Sino-Japanese Relations: Facing the Past, Looking to the Future? London: Routledge.

Rozman, Gilbert 2004. Northeast Asia's Stunted Regionalism: Bilateral Distrust in the Shadow of Globalization. New York: Cambridge University Press.

Sawa, Kijirō 2007. 'Chūgoku no Tōhoku Kōtei to Chōsenshi Shinryaku to Kita Chōsen' [China's Northeastern Process, Invasion in Korean History, and North Korea]. Yamaguchi Keizaigaku Zasshi [Yamaguchi Economics Journal] 55 (5): 135-137. 
Schellstede, Sangmie 2000. Comfort Women Speak: Testimony by Sex Slaves of the Japanese Military. New York: Holmes and Meier.

Shen, Simon, and Shaun Breslin (eds.) 2010. Online Chinese Nationalism and Chinese Bilateral Relations. Lanham, MD: Rowman and Littlefield.

Shin, Bok-ryong 2012. '동방삼국을 바라본는 당태종의시선: 동북공정의원류를 찾아서 [The Perspective of Tang Taizong towards the Three Eastern Kingdoms: Searching for the origins of the Northeast Project]. In한반도 분쟁과 중국의 개입 [Conflict in the Korean Peninsula and China's Intervention], edited by J. S. Lee and S. H. Jo, pp. 17-49. Seoul: Sunin.

Stockmann, Daniela 2011. 'Race to the Bottom: Media Marketization and Increasing Negativity Toward the United States in China'. Political Communication 28 (3): 268290.

Sullivan, Jonathan 2012. 'A Tale of Two Microblogs in China'. Media, Culture E Society 34 (6): 773-783.

Sullivan, Jonathan 2014. 'China's Weibo: Is Faster Different?' New Media \& Society 16 (1): 24-37.

Townsend, James 1996. 'Chinese Nationalism'. In Chinese Nationalism, edited by J. Unger, pp. 1-30. Armonk, NY: M.E. Sharpe.

Wang, Q. Edward 2001. Inventing China through History: The May Fourth Approach to Historiography. Albany, NY: State University of New York Press.

Wang, Zheng 2012. Never Forget National Humiliation: Historical Memory in Chinese Politics and Foreign Relations. New York: Columbia University Press.

Weiss, Jessica 2013. 'Authoritarian Signalling, Mass Audiences and Nationalist Protest in China'. International Organization 67 (1): 1-35.

Weiss, Jessica 2014 (forthcoming). Powerful Patriots: Nationalist Protest in China's Foreign Relations. Oxford: Oxford University Press.

Yang, Guobin 2009. The Power of the Internet in China: Citizen Activism Online. New York: Columbia University Press.

Yi, Jae-hyung 2007. 중국의 해양전략 [China's Maritime Strategy]. Seoul: Gold Egg.

Yi, Jong-Uk 2005. 고구려의 역사 [The History of Goguryeo]. Seoul: Gimyoungsa.

Yi, Sang-hyun 2012. '중국의 부상과 미국의 대응: 한국에 대한 안보적 함의' [The Rise of China and the Response of the US: Security Implications for Korea]. In 한반도 분쟁과 중국의 개입 [Conflict in the Korean Peninsula and China's Intervention], edited by J. S. Lee and S. H. Jo, pp. 253-286. Seoul: Sunin.

Yi,Sung-si 2001. 만들어진 고대: 근대 국민국가의 동아시아 이야기 [Created Antiquity: The Early Modern Nation-State's Story of East Asia]. Seoul: Samin.

Zhang, Shuguang 1995. Mao's Military Romanticism: China and the Korean War, 1950-1953. Lawrence, KS: University Press of Kansas.

Zhao, Suisheng 2013. 'Foreign Policy Implications of Chinese Nationalism Revisited: The Strident Turn'. Journal of Contemporary China 22 (82): 535-553. 